\title{
An Eco-Critical Inquiry of John Keats and William Wordsworth's Selected Poems: A Comparative Study*
}

\author{
Saman Ali Mohammed \\ Department of English - University of Human Development, KRG, Iraq
}

\begin{abstract}
Literature has uniquely played a fundamental role as a reproductive medium or stage where great theories are experientially shown from which one can gain better understanding of human place, its characteristics and human refinement in such a place. Eco-critically exploring the ways that these authors have depicted land and/or nature in their writing, this research argues that their works philosophically display a consciousness of the nature of man and the natural world and exhibit an ecological and environmental consciousness.
\end{abstract}

The romantic poets were deeply concerned about what nature is and what one can gain from it, and this research attempts at eco-critically discovering the very linkage these writers have portrayed between culture and nature. This research maintains that there are eco-critical characteristics in their approach to the relationship between human being and his natural surroundings. These poets' concerns about the nature-human relationship tend to be an inquiry on the condition and the place of man. Portraying their understanding of the existence of the natural elements and their evaluation of human existence, culture, and the individuals' lives are crucial aspects of their artistic legacy.

Key Words: Eco-criticism, Nature, Beauty, Culture and Nature, Civilization

* The paper has been presented in the 4th International Scientific Conference of University of Human Development, April, 2017.

\section{Aims and Objectives}

One of the most crucial humanitarian contemporary concerns is the environment. While we live nowadays amidst the ecological threats that the industrial revolution has brought about, nineteenth century literature especially the romantic period, which mirrors individual and social issues, would be among the best places to trace back such a concern to its starting point to examine a poetic representation of the relationship between culture and nature from an eco-critical perspective. This research will provide a potential background to examine the human values, such as uniqueness, authenticity, freedom, dignity, caring, integrity, benevolence, coexistence, morality, love, and diversity which were at risk at that time as shown in the literary texts and to study the interdependence of human-respecting cultures and a purer nature, looking for any harmonic relationship between man and land in those works. The research's contribution will be mainly about possibly using this relationship as a lens to reread those works, to shed light on the philosophical, psychological and historical antecedents of our current ecological crisis, and how the selected texts' concepts of nature can possibly be used to reread our understanding of concepts such as gender, race, class, and nation.

\section{Scope}

The study is limited to the selected poems of John Keats and William Wordsworth. The selection is informed by the concern for the projected themes of nature and the individual styles and techniques of the poets. Two poems of each were purposively selected for eco-critical and comparative analyses. The justification for the choice of John Keats and William Wordsworth is informed by their unique 
poetic visions and techniques as well as their love for the natural environment and poetry as the medium for poetic expression.

\section{Specific Research Questions}

1. What figurative rhetorical moves are used by poets, and what can we learn from them about our cultural attitudes towards nature and human development?

2. To which extent does place offer a distinctive lens through which we can read literature and see the world in nineteenth century?

3. Potentially, can eco-criticism step up from survival needs towards addressing higher human psychosocial needs as shown in the selected works?

4. Can an eco-critical analysis of the selected poems be seen as a mediator between culture and nature, or between writing and land, as a mirroring tool?

5. Apart from a purely environmental consciousness, eco-critically what are certain human values in relation to land that are portrayed in these authors' artistic works? Why?

\section{Eco-criticism: Literature Review}

Biologist and philosopher professor Ernst Haekel first used the term ecology in 1869 as the study that analyzes "the relations of organisms to one another and to their physical surroundings [and] the study of the interaction of people with their environment" (Marsden 30). Later, William Rueckert in 1978 in his essay "Literature and Ecology an Experiment in Eco-criticism" used the term eco-criticism by which he meant "the application of ecology and ecological concept to the study of literature" (Glotfelty xx). In their The Eco-criticism Reader (1996), Cheryll Glotfelty and Harold Fromm define ecocriticism as "the study of the relationship between literature and the physical environment" (xviii). According to Glotfelty and Fromm, the ecological criticism of nineteenth century portrays fundamental views of the relationship between human culture and the physical world surrounding it, which is "affecting it and affected by" (xix). ${ }^{1}$

One of eco-criticism's basic premises is that "literature both reflects and helps to shape human responses to the natural environment" and by studying representation of the physical world in literary texts and social contexts of their production, eco-criticism accounts as well for their attitudes and practices that have been attributed in the texts (Hutchings 172). Eco-criticism "takes as its subject the interconnections between nature and culture, specifically the cultural artifacts of language and literature. As a critical stance, it has one foot in literature and the other on land; as a theoretical discourse, it negotiates between the human and the nonhuman" (Glotfelty xix). Such interconnections and ecological consciousness expand and further extend human understanding of the importance of both human as well as non-human context. Thus, it requires treating the non-human world as crucial and serious as the realm of society and culture (Love Practical Eco-criticism: Literature, Biology, and the Environment 47). The project of eco-criticism can be summarized as "the examination of nature through words, images, and model for the purpose of foregrounding potential effects representation might have on cultural attitudes and social practices which, in turn, affect nature itself" (Hochman 30).

The research will try to apply an analytical and educational strategy used unconsciously by children in an effective way. They destroy a provided readymade order that already exists, to discover other possible orders by themselves. When someone puts some blocks for children in a certain order, first they knock them down, then they compare the scattered mess with the previous order, and finally they start rearranging the parts in a new possible order that makes sense and means a lot for them and for people around. The research will deconstruct the literary scenes that are imaginatively drawn by the selected authors, searching for essential meaningful parts, images and key words that will be used afterwards critically to recollect pertinent plausible

\footnotetext{
${ }^{1}$ Mohammed Saman. "Culture and Nature: Thomas Hardy's the Return of the Native" International Review of Social Science
} 
understandings about the ways they would address the interface between land and literary scenes.

\section{Introduction}

Free expression and revolutionary will along with radical confrontation with what is conventional and rational are unique characteristics of Romanticism. Unlike restoration, romanticism sees poetry as a deeper, personal and somehow mystical medium where it can echo human imagination, natural world as well as human emotion that are vital features defining romanticism (Ayinuola 13, Sanders 335).

The interest of English literary artists in the natural environment dates back to the romantic period (1798-1832), when England was transformed from an agricultural society into an industrial one. The industrial revolution with the attendant mechanization of life at the period brought about the destruction of landscapes, general chaos, changes both in the landscape and in the social lives of the people. Romantic writers celebrated the freedom in nature and individual experience (Ayinuola 12). Ronald Carter and John McRae's view that the romantic period embodies:

Many of the conflicts and ideological debates which are at the heart of the world; political freedom/repression, individual/collective responsibility, masculine/feminine roles, past, present and future. It was a time when ideologies were in the melting pot, when radicalism and tradition, change and stability, the old and the new were just as vital as the more traditionally literary themes of innocence/experience, youth/age, country/city, man/nature, language/expression (202).

The thematic representation of human culture is shown in the heart of natural life through the word choice, images as well as literary techniques in the poem. The poems selected are dominated by natural themes such as the wilderness, the countryside as well as man-made natural environment in relation with human life. Rereading and examining the natural elements and the environmental scenes in the literary poems is eco-criticism. Reevaluating natural elements in poetry is to show the creative power of a culture that has nature as its mirror.

\section{William Wordsworth (1770 - 1850)}

As a young man William Wordsworth (1770-1850) was major English Romantic poet who with Samuel Taylor Coleridge launched the Romantic Age with their joint publication Lyrical Ballads (1798). Wordsworth was a "rebel, questioning political, religious, literary and emotional conventions" (Thorne 195). He rejected the established religion and this could free him from the restrictions of the eighteenth-century church and allowed him to "develop his own kind of spirituality - a belief in the omnipresent spirit of the natural world" (Thorne 195). For Wordsworth the best mode of expression was poetry and if he has written in any other form it has been to restructure his poetic expression. He is remembered as "a poet of spiritual and epistemological speculation, a poet concerned with the human relationship to nature" (William Wordsworth n.a). Wordsworth is also referred to as the "nature poet". He was popular with writers like Mathew Arnold who was interested in Wordsworth's presentation of nature as a "transcendent force" that with contemporary Arnold found "certainty in a time of spiritual doubt". For Arnold's community Wordsworth's work was an escape from the mechanistic world of the industrial revolution (Thorne197).

The purpose of the Prelude (1798) was to trace the growth of the mind of the poet by writing about the things that had influenced his development, so the poem is both personal and philosophical although it is an autobiographical piece. It led him finally to accept who he was and what made him who he was (Thorne 197). In the Preface Wordsworth states his opinion about the poetic aims that "the function of art is to write about things not as they are, but as they appear. The poet must draw on his senses and passions in order to reach below the surface of the things to a deeper understanding" (Thorne 193). Poets like Wordsworth and Coleridge "looked for truth 
and meaning in the natural world; because reason and impersonality had alienated man from his feelings, they valued the emotions as a means of reconnecting man with his inner life" (Thorne 193). For him poetry is "the spontaneous overflow of powerful feelings: it takes its origin from emotion recollected in tranquility" and a poet is "a man speaking to men; a man ... endowed with a more lively sensibility, more enthusiasm and tenderness, who has a greater knowledge of human nature, an a more comprehensive soul ... a man ... who rejoices more than other men in the spirit of life that is in him" (qtd Thorne 193-4).

"Lines Written a Few Miles above Tintern Abby" by William Wordsworth

"Lines Written a Few Miles above Tintern Abby, on Revisiting the Banks of the Wye During a Tour, July 13, 1798" or often abbreviated as "The Tintern Abby" is a nature poem by William Wordsworth. Since the countryside or the river wye is a place he has already visited, the wonder is his speculation of what it meant to him, and how it has made him think and feel. The poem was written when he was twenty three years old, yet since then he had begun his relationship with Samuel Taylor Coleridge. Since the poem has a sense of conversation, there seems to be a silent listener who in this case is his sister Dorothy who is addressed in the later parts of the poem. The poem generally engages with intense intellectuality and philosophy on the ideas of man-land relationship. Tintern Abbey is one of the important nature poems of Wordsworth since such poems show him as "a nature poet who finds a common bond between the natural world and the inner self' (Thorne 196).

Five years have past; five summers, with the length

Of five long winters! and again I hear These waters, rolling from their mountain-springs With a soft inland murmur.--Once again Do I behold these steep and lofty cliffs, That on a wild secluded scene impress
Thoughts of more deep seclusion; and connect The landscape with the quiet of the sky.

Remembering the time he was away, he shows the state of the landscape and how it made him feel. The scene of the "waters" and "mountain-springs" are presented as a friend he knows well and is well aware of their "soft inland murmur". The natural environment helps him experience a higher level of being. A state that he can't help but poeticize it "Once again/ Do I behold these steep and lofty cliffs,/ That on a wild secluded scene impress/ Thoughts of more deep seclusion". He is a human being with elements of culture that has mingled with elements of nature that makes him unique. Uniqueness is a quality that elements of nature carry, for instance, in the case of a flower, it is one independent with one special identity. Apart from his highest concern of human identity in the palms of natural identity, towards a mechanized community Wordworth has chosen to familiarize us with a danger when nature is absent and what it can make of us. The question of nature is central to the question of art and in this medium, Wordsworth has touched upon two main concerns: one environmental, and the other pscho-sociological. The study of ecocriticism, which began to take shape most distinctly in the environmentalist urgency of the 1980s, has given voice to much of this questioning over the past decades.

These beauteous forms,

Through a long absence, have not been to me As is a landscape to a blind man's eye: But oft, in lonely rooms, and 'mid the din Of towns and cities, I have owed to them In hours of weariness, sensations sweet, Felt in the blood, and felt along the heart; And passing even into my purer mind, With tranquil restoration:--feelings too Of unremembered pleasure: such, perhaps, As have no slight or trivial influence On that best portion of a good man's life, His little, nameless, unremembered, acts Of kindness and of love. 
In the later parts of his long poem, he recalls the scenes such as a "Cottage-ground", "orchard-tufts", "hedgerows", "sportive wood", "pastoral farms", "trees", as "These beauteous forms/ through a long absence, have not been to me/ as is a landscape to a blind man's eye:" Wordsworth emphasis his understanding and imagination of what he has experienced earlier through his use of "blind man's eye". He is a seer and a wonderer that has absorbed the very truth about nature. The resonation of his moments in the natural world and what he has felt can prove the depth of his perception as he "owed to them", "In hours of weariness, sensations sweet/ felt in the blood, and felt along the heat;". Thus nature is a source of temporary aesthetic and emotional feelings which even if they are; they have been a pure source of joy which psychologically have made him natural human being as such "unremembered pleasure" have no "slight or trivial influence/ on that best portion of a good man's life/ His little, nameless, unremembered, acts/Of kindness and love". The pleasure, kindness and love are fundamental human values that would be backbones of a purer and more refined culture. Such feelings have also passed into the "purer mind" and enriched him with "tranquil restoration"; a state that is deeper than a feeling but has become a spot of memory as Thorne maintains "Wordsworth uses memory as a source of inspiration, and intertwines particular incidents and scenes with reflective, abstract thought" (196). Wordsworth owes a universal pure human state of tranquility to nature that he calls "another gift" being "that serene and blessed mood" that has lightened him to a state of non-existent but rather spiritually existing:

And even the motion of our human blood Almost suspended, we are laid asleep In body, and become a living soul: While with an eye made quiet by the power Of harmony, and the deep power of joy, We see into the life of things.

The speaker here is almost numb bodily but "a living soul" who can see and feel. Wordsworth suggests his own harmony of mind and body that as a traveller sees "into the life of things". The poet speaks of the sublime blessing that is received from his deep contemplation of the beauteous aspects of nature. The psychological aspects of a human being are suspended for the time being in nature. The body becomes inactive and the soul becomes active. Then only the worshipper of nature can realise the hidden truth of nature and his art has extended this experience to his readers. Wordsworth perceived in his experience a supernatural import. He became aware of a vast spirit that was the reality of nature. Belief in such a being was inspired by the insights and speculations Wordsworth had. Thus, to him things were alive and embedded in a vast soul and they were part of a moral system of being.

"The universe itself," wrote Coleridge in 1797, "what but an immense heap of little things?-I can contemplate nothing but parts, \& parts are all little-! -My mind feels as if it ached to behold \& know something great- something one \& indivisible-and it is only in the faith of this that rocks or waterfalls, mountains or caverns give me the sense of sublimity or majesty!" (qtd Heffernan 605). This profound yearning for transcendent unity, this passion for the "one life" so characteristic of Coleridge throughout his life, was likewise a vital element in the poetry of William Wordsworth. Wordsworth could never accept a universe of fragments (Heffernan 605). Similarly, in "Tintern Abbey,", he states:

A motion and a spirit, that impels

All thinking things, all objects of all thought, And rolls through all things. Therefore am I still A lover of the meadows and the woods, And mountains; and of all that we behold From this green earth; of all the mighty world Of eye, and ear,--both what they half create, And what perceive; well pleased to recognise In nature and the language of the sense,

For Wordsworth, "nature was neither reducible nor divisible; it could only be embraced in its complexity, seen at once as multiple and unified" (Heffernan 613). According to Stallknecht, Wordsworth's experience helped him to view nature as a living power. Nature and not our faculty of comparison makes one object suffuse another. After all, no matter how acute one's taste, natural beauty does appear to be 
a gift, not a creation of our own. Thus, nature does seem to be the artist and the artist becomes nature which better signifies the relationship between both culture and nature. Nature seems to have actively penetrated into man's mind and act upon it and thrust beauty upon us. Stating that nature is "A motion and a spirit, that impels 0/ All thinking things, all objects of all thought,/And rolls through all things" would wonder and question anyone that what is not a "motion" or a "spirit"? Thus, for him there is no division but a unity being a universal value interconnecting both nature and culture. His voice is of a world that is creative through thinking of the very natural elements around as being the force for such recreational process. As Heffernan states, "Throughout his life, Wordsworth sought in natural objects a reflection of the universal, the permanent, the ideal, and the eternal. What distinguishes the later years from the earlier ones is not a repression of feeling but a clearer sense of its direction, a sharper comprehension of the emblematic values which the deeper kind of response can discover" (614).

Unity and uniqueness are values that nature has and Wordsworth appreciates such values as they refine and cultivate him and as a result a culture. For him nature has been "The anchor of my purest thoughts, the nurse,/The guide, the guardian of my heart, and soul/ Of all my moral being." Wordsworth, it is known, was deeply influenced by the spiritual impact of nature. In these lines, Nature is the light and knowledge where he can learn the mysteries of life, experience the joys and find himself in a spiritual relationship with it. Unlike a mechanized society, then, nature is where man can be different and unique. The ideas and concepts Wordsworth formulated are still of great importance, in particular in current times of progressing globalization, environmental pollution and degeneration of nature. The state of mind recalled here was not product of an escape from man to nature, as has been repeatedly conjectured. Thus an ecocritical reading of his poem dives into a deeper and higher level of needs that are spiritual and moral although argumentatively one could say he has been aware of the contemporary environmental concerns. As Potkay states "During the nineteenth century, things were increasingly taken to be that which was not human, especially manufactured objects ... Therefore, it's time to improve the existing environmental problems through literature or other possible ways (401).

To be a better human being rather than a copied model and to be pleasant and loving as natural elements, Wordsworth has chosen nature as his source that even helped him experience high morality as he has rejected the accepted constitutions and morals. That is why he is still "A lover of the meadows and the woods,/ And mountains; and of all that we behold/ From this green earth;". It is really from William Wordsworth the practice of loving and adorning nature in more specialized manner came into light (Reddy 40). The pictures in mind are coming from external experiences in contact with the body and human senses. In a world driven by scientific gaze and thoughts speculated in alienation of civilization, Wordsworth reminds us about very human and cultural values by presenting his thoughts of the values he has gained from nature as he states: "We stood together; and that I, so long/A worshipper of Nature, hither came/Unwearied in that service". In a stage of spiritual insightfulness, Wordsworth questions God and the force behind the world that goes through everything. As Reddy maintains that Wordsworth has experienced or found the power of the natural world and he has "stood tall for his devout hermit sort of worshiping of nature. He was a pantheist. He found nature as a means ensuring man's unity with his Creator" (Reddy 41). Wordsworth portrays what nature has given unlike culture and that "Nature will never betray the heart that loved her" and one can infer the responsibility in a modern society is to "safeguard Nature from all manmade dangers and all environmental hazards, it will in return guard, nurse and guide them" (Britto 725).

William Hazlitt remarks about this aspect of William Wordsworth's poetry:

He sees nothing loftier than human hopes; nothing deeper than the human heart. This he probes, this he tempers with, this he poises, with all its incalculable weight of thought and feeling, in his 
hands; and at the same time calms the throbbing pulses of his own heart, by keeping his eye ever fixed on the face of nature. If he can make the life blood flow from the wounded breast, this is the living colouring with which he paints his verse: if he can assuage the pain or close up the wound with the balm of solitary musing, or the healing power of plants and herbs and 'skyey influence, 'this is the sole triumph of his art......In a word, his poetry is founded on setting up an opposition between the natural and the artificial; between the spirit of humanity, and the spirit of fashion and of the world! (252-253)

Knowing that Nature never did betray The heart that loved her; 'tis her privilege, Through all the years of this our life, to lead From joy to joy: for she can so inform The mind that is within us, so impress With quietness and beauty, and so feed With lofty thoughts, that neither evil tongues, Rash judgments, nor the sneers of selfish men, Nor greetings where no kindness is, nor all The dreary intercourse of daily life, Shall e'er prevail against us, or disturb Our cheerful faith, that all which we behold Is full of blessings. Therefore let the moon Shine on thee in thy solitary walk;

The source of learning or rather knowledge of world is the nature that Wordsworth adores and believes it will "never betray/ The heart that loved her". In the above lines of his poem, Wordsworth presents realities of both culture and nature he has conceived, the very experience he had, and the stories to be told. He depicts the purer and cultivating concept of nature as personified as a mother that "informs" being a sources of giving to "the mind that is within us". This process of being a guide is not pure scientific but rather saturated with "quietness and beauty"; values that certain instituitions and rules in the community might distort. Wordsworth presents the unique individual as another unique element in nature and mingled with nature. He also presents a world of a corrupted civilization that is full of "evil tongues", "rash judgments", "sneers of selfish men", "greetings where no kindness is", "the dreary intercourse of daily life". However, the mingling of the individual or culture with nature will prevent such evils to "prevail against us, or disturb/ our cheerful faith, that all which behold/ is full of blessing". Prominent in eco-criticism is a critique of binaries such as man and nature or culture and nature, viewed as mutually exclusive oppositions. As Reddy maintains, "these entities are interconnected, and mutually constitutive. Our identities, or sense of self, for example, are informed by the particular place in which we live and in which we feel that we belong and are at home (Reddy 47).

\section{"The Tables Turned" - Poem by William Wordsworth}

In his "The Tables Turned", Wordsworth nicely portrays the relationship, reconciliation and/or divorce of culture and nature or one can safely say nature and civilization. In this poem, the society, the cultural perspectives on knowledge and science is presented negatively unlike a positive representation of natural gaze and experience. Wordsworth suggests nature to be a mirror for culture when culture can fix its universal human values in nature. In the poem, Wordsworth describes culture as highly influenced and shaped by empirical and rational thinking, thus appearing to be "dull" and "strife". Having a historical background saturated with industrialization and urbanization, the situation of man and nature were in danger in favor of a civilized community mechanically and technologically.

Up! up! my Friend, and quit your books;

Or surely you'll grow double:

Up! up! my Friend, and clear your looks;

Why all this toil and trouble?

Knowledge and civilization are portrayed as "toil and trouble", hoping people would get an understanding of a refined culture from nature as "There's more of wisdom in it" thus it is not a mere imaginative and pleasing source but a powerful source of knowledge and learning unlike the rational learning of civilization where man might be a mere tool rather than the creative force as he concludes his poem:

Enough of Science and of Art; 
Close up those barren leaves;

Come forth, and bring with you a heart

That watches and receives.

He appreciates a wisdom that has come from nature and saturated with feeling "Sweet is the lore which Nature brings;" Nature for him is the phenomena that doesn't reject anything but rather has "a world of ready wealth," and can be a source where"Our minds and hearts to bless - / Spontaneous wisdom breathed by health,/Truth breathed by cheerfulness." He also states that: "One impulse from a vernal wood/ May teach you more of man,/Of moral evil and of good,/Than all the sages can." Such a believe in the power of natural world is unique and comes from an experience that is full of insights, speculations, realizations and joy. Wordsworth believes that man's innate goodness develops in the pure company of nature. In such an environment men are stripped of all utilitarian motives and their humanness is restored. They are purified of all the vain influences of the social world and their pure and permanent nature is revealed. Sunil Sarker points out that in his poetry Wordsworth wanted to teach men the value of humaneness, goodness and morality. The destructions and miseries that a corrupted culture has brought about led him to think and conceive of an ideal society where he would see liberty, love, brotherhood, sympathy and piety. Sarker says:

Indeed whatever belonged to human beings and whatever feelings human beings possessed were empathetically shared by Wordsworth; of course, he shared the most those feelings that belonged to the meek, the innocent, and the oppresses or the beguiled or befuddled. His heart always went to the miseries of human beings......Wordsworth's humanitarian zeal, and particularly his sympathy for the underdogs and misfits of the society, showed themselves in relief mostly in his poems written between 1793 and $1798 \ldots . .(2001,334-335)$

Wordsworth's poetry portrays what would be a prophetic insightful into human life through nature. Thus his presentation and concern of nature can better identify the higher human needs and the very values culture should recreate having nature as a guide.

\section{John Keats (1795-1821)}

Keats died from tuberculosis just before his twenty fifth birthday. His letters show disciplined approach to poetry "rich expression", "technical control" and, "the power of physical experience as the essential elements of true poetry" (Thorne 207). John Keats had perhaps the most remarkable career of any English poet. His development as a poet was slow until his art suddenly, in the course of a few years, shot forth into its maturity. He had a wide range of poetic forms: "from the sonnet, to the Spenserian romance, to the Miltonic epic, defining anew their possibilities with his own distinctive fusion of earnest energy, control of conflicting perspectives and forces, poetic self-consciousness, and, occasionally, dry ironic wit. In the case of the English ode he brought its form, in the five great odes of 1819 , to its most perfect definition." (John Keats n.a). He is one of the romantic poet as his perspective on the "creative power of the imagination was to link him directly to the Romantic Movement" (Thorne 207).

The character of Keats rather reflects his perception and insights on nature as through his life his friends remarked on his industry and his generosity. The loss of his father and mother affected him, yet he believes in "seeing personal experience as the means of understanding the self and society, he challenges the conventions of traditional religion and explores human experience and the tension between the real and the ideal" (Thorne 208). Among many other concerns "literature for Keats was a career to be struggled with, fought for, and earned, for the sake of what the poet's struggle could offer humankind in insight and beauty." (John Keats n.a). For him poetry should be "great and unobtrusive, a thing which enters into one's soul, and does not startle it or amaze it with itself but with its subject ..." (Letter to John Hamilton Reynolds, 1818 qtd in Thorne). He believes that "what imagination seizes as Beauty must be truth" (Letter to John Taylor, 1818 qtd in Thorne), and further believes that poetry should elevate, mounted and high suggesting the ways the poet rises about the real. As Sarah Thorne states, "the 
influence of Wordsworth can be seen in Keats's view of the natural world as a mirror of our state of mind" (208). Literature and its representation of nature present universal human values as a far-fetched insightfulness towards reality. The intensity of his experience lies in the ability to participate in the things that exist outside of himself as if he sees a sparrow, he can "take part in its existence and pick about the gravel. He was interested in the insights such experience could provide, but not in rationalizing it" (Thorne 208).

In a letter to his brothers George and Thomas (1817) he states that negative capability is "when a man is capable of being in uncertainties, mysteries, doubts, without any irritable reaching after fact and reason" (qtd Thorne 208). His experience is a deeper insightfulness than any ordinary people that "implies an engagement in the actual through imaginative identification that is simultaneously a kind of transcendence. The artist loses the selfhood that demands a single perspective or meaning, identifies with the experience of his/her object, and lets that experience speak itself through him/her. Both the conscious soul and the world are transformed by a dynamic openness to each other. This transformation is art's truth, its alliance with concrete human experience; its beauty is then its ability to abstract and universalize from that experience the enduring forms of the heart's desires" (John Keats n.a).

\section{“A Thing Of Beauty (Endymion)" by John Keats}

$\begin{array}{llllll}\text { A thing of beauty is a joy for } & \text { ever: } \\ \text { Its lovliness increases; } \text { it } & \text { will } & \text { never } \\ \text { Pass into nothingness; but } & \text { still } & \text { will } & \text { keep } \\ \text { A bower quiet for us, and } & \text { a } & \text { sleep }\end{array}$

Full of sweet dreams, and health, and quiet breathing.

Keats is keen in understanding human lives, the suffering and experiences we have in life. His perception of beauty and its relationship with human life reflects his perspective of nature as well as human being. In the first line of "A Thing of Beauty (Endymion)", Keats makes a great statement about beauty when he links it with a human emotion "joy". Statements on human joy not only philosophically indicate Keats thoughts on joy as a universal human value and need but also his penetrated thoughts into deeper part of human psyche. What is "a thing of beauty" that "is a joy forever" and has the quality that "never pass into nothingness"? It can only be nature as a special characteristic of the romantics that is an existence that carries unique human values.

That "thing of beauty" does "keep" human "a bower quiet", "a sleep full of sweet dreams, and health, and quiet breathing". Such description better signifies a common understanding of nature as a quiet place that physiologically and environmentally speaking keeps a clean and healthy environment for "us" as well as a universal truth on a higher human need "joy" and "beauty". What will human being become in the absence of "beauty" and "joy" is the underling question in his poem. Keats has gone beyond the common environmental concern of nature but rather emphasizes the immortality of beauty in our mortal life. Keats seems to suggest that beauty and nature will make us unique existence, natural and interesting as opposite to an example of us, empty of feeling, an uninteresting copy that is similar to the industrial world.

Therefore, on every morrow, are we wreathing A flowery band to bind us to the earth, Spite of despondence, of the inhuman dearth Of noble natures, of the gloomy days, Of all the unhealthy and o'er-darkn'd ways Made for our searching: yes, in spite of all, Some shape of beauty moves away the pall From our dark spirits.

"A thing of beauty" that can be nothing but also metaphorically "joy" can also be nature. Reading through the poem, one can realize that Keats has given the medication, the solution or the answer to what to do with certain human conditions and it is "a thing of beauty" that is "a joy forever". Nature is the medication in the scientific perspective; however as a unique existence this poem and its representation of nature is as literature is universally unique which is a 
commonality between them. Therefore, in this poem it is flowers that should "bind us to the earth" and help us to forget or rather rethink the human condition of "of the inhuman dearth Of noble natures" "gloomy days", "unhealthy and o'erdarkn'd ways". It is his unique insight onto human emotions and its very relationship with the external existences that has led him to emphatically state that "some shape of beauty moves away the pall/ From our dark spirits". Keats here had seen through human internal being in depth that he is aware of the vital effectiveness of beauty and nature on human spirit. His perspective is almost like a doctor and a psychotherapist that knows the issue since he is a seer and a thoughtful human being. As Fortress Isaiah Ayinuola states "Keats on one hand is uniquely a poet of beauty (45)". Keats himself, refers to immortal works of beauty as "souls of poets", that serve as the means by which they "hold lofty converse with after times" (Eruvbetine 253).

The metaphorical statement of his poem becomes clear in the later parts of his poem when he gives examples of "a thing of beauty".

$\begin{array}{cccc}\text { Such } & \text { the the moon, } \\ \text { Trees old and young, sprouting a shady boon }\end{array}$ For simple sheep; and such are daffodils With the green world they live in; and clear rills That for themselves a cooling covert make 'Gainst the hot season; the mid-forest brake, Rich with a sprinkling of fair musk-rose blooms: And such too is the grandeur of the dooms We have imagined for the mighty dead; An endless fountain of immortal drink,

Pouring unto us from the heaven's brink.

Thus, one can see certain elements of nature "such the sun, the moon/ trees old and young, sprouting a shady boon/ for simple sheep, and such as daffodils/ with green world they live in; and clear rills ... the mid-forest brake/ rich with a sprinkling of fair musk-rose blooms". These examples can explain his unique perception of the natural world as a special existence that is where man finds himself, can experience the inexperienced parts of himself, and delve into his own experimental search for the higher cultural and psychological needs. Keats perspective also indicates the uniqueness of man and his resonation with nature in the absence of certain human conditions which would otherwise drag him back into a world of copy not uniqueness.

A poet is everyone and yet no one. As a poet Keats has gone beyond the mere world of objects and natural elements but rather thought through his existence in relation with these very natural elements. As he states in one of his letters that "A Poet is the most unpoetical of anything in existence; because he has no identity-he is continually in forand filling some other Body" (L 1:387). He has given no identity to himself or anyone else. Philosophically he has familiarized man with the familiar and the unfamiliar. Anyone who has gone as deep through his poems would no longer have the identity they had before. As Irving White states in his article "John Keats as a Critic", that "Keats developed his critical powers by thinking for himself" and "If Keats was a good critic of others, he was a better critic of himself' which can better signify that "Keats is one of the few poets in whom the poetical and critical faculties were united almost equally" (450, 454, 465). Although White discusses Keats character as a critic as well as a poet among his peers, his perspective is also true when it comes to Keats as the poet who is a keen observer of his own feelings when writing poetry. He is well aware of his internal faculties and the external factors.

The years 1818 to 1820 saw an intensely creative period of Keats's life, it was during this same period that he wrote the Odes in which the rich and sensuous variety of human experience is set against the transience of human life. "In this constellation of Romantics, John Keats had his own unique vision of looking at nature. He didn't drive himself to nature for energy or shelter's sake, as done by his predecessors ... He adorned nature for its beauty ..." (Reddy 41). Keats has preoccupied and rather fed deeply by beauty and nature that in his "Ode on a Grecian Urn" he addresses and appreciates the beauty of it. The pictures of the elements of nature are painted and frozen in time as they are "sill unravish'd bride of 
quietness," the "foster-child of silence and slow time". Even if civilization destroys the very wild and unique nature, the portraits of the natural elements will still carry the very universal values Keats believes in. He describes the urn as a "historian" which can suggest how nature can maintain beauty. Very much like the Urn, his poetry has preserved the natural world as a bit of ecological truth provided that his piece is an art with a timeless universal value and this can further reinforce the commonalities between man-land. The Urn can also be interpreted as a picture in the imagination of the poet himself suggesting a better understanding of nature that can keep a fresh soul with a unique passion.

The second stanza that maintains the story of the young lovers suggests the undying beauty of the two in the palms of the natural elements as these elements such as the tree will not shed the leaves. Keats speculation on the state of man in nature is better conceived by the state of emotion and the condition of man in the nature frozen on the Ure in the third part "More happy love! more happy, happy love!”. In the last part of his famous "Ode on a Grecian Urn", Keats presents the image of a group of villagers and questions them "To what green altar, O mysterious priest ..." Such presentations of man and nature uniquely presents the resonation of the natural values in the natural elements and the very healthy and meaningful relationship between culture and nature that should be preserved. To any reader it is just a presentation of an Urn, yet one should not forget the very interconnectedness of man and land that needs to be immortally presented and the Urn is a very good option and his poem as a literary truth is a better one.

The final two lines of his "Ode on a Grecian Urn" is a powerful statement on beauty "Beauty is truth, truth beauty, - that is all/ Ye know on earth, and all ye need to know." This might be his ultimate perception on beauty and nature that he believes that even any thing beautiful is truth. If it is the speaker addressing the Urn, then it can suggest the limitations of it, yet on the other hand, if the Urn is addressing man, it is a powerful lesson on the condition of man. The question would be, what is beauty? The common understanding is that it is in the eye of the beholder. Yet, based on the descriptions and insights of Keats, the very experience one can gain in the natural world is beauty and so it is truth as it can help us gain access to our better being, it will cultivate certain faculties that our engagement with civilization wouldn't be able to cultivate. It can refine us to become a loving human being by experiencing as well as appreciating the values that nature has maintained for us such as authenticity, freedom, dignity, caring, integrity, coexistence, variety, and tolerance as presented in the community on the Grecian Urn.

Emmanuel Kant, in his Critic of Pure Judgement (1790) compares the difference between the Beautiful and the Sublime. Kant maintains that beauty is related to the form of the object, and unlike beauty sublime represented in the boundlessness and is in the formless. Whereas beauty relates to understanding, the sublime is a concept belonging to reason, and shows a faculty of the mind surpassing every standard of sense (25). Christopher Hitt in his article Toward an Ecological Sublime states the position of reason and nature in a world driven by technology and scientific discoveries

"The technological solution is ultimately a dead end because, contrary to Kant, reason can never master nature. There will always be limits to our knowledge, and nature will always be, finally, impenetrable. An ecological sublime would remind us of this lesson by restoring the wonder, the inaccessibility of wild nature. In an age of exploitation, commodification, and domination we need awe, envelopment, and transcendence. We need, at least occasionally, to be confronted with the wild otherness of nature and to be astonished, enchanted, humbled by it. Perhaps it is time?while there is still some wild nature left?that we discover an ecological sublime" (620).

Keats has helped everyone that reads him to confront nature and the wildness that has the beauty as a cultural value as well as being a natural value. In this poem Keats hits two target with one stone as he portrays art as painted on the Urn but also his poem that both preserve human-nature connectedness. As 
Sanders maintains "the poem allows for the high compensations offered by art ..." that later Keats calls the Urn "a friend of man" (389). The Urn has the quality of being immortal thus both being beautiful and truthful are effectively portrayed on the Urn. It is free from dying and such state of permanence makes it unique as it carries unique cultural values. Thus, the link between culture and nature from an ecocritical perspective is preserved.

Keats's nature poems focus on the physical reality and influence of nature on his inner being and poetic creativity. Wordsworth emphases abstraction, didactic and religious fulfillment, Keats see himself as part of the natural environment and so represent the environment in his lives and poetry. This is also one of our determining factors in our choice of specific nature poems common to both poets.

\section{Conclusion}

Literature has been able to give birth to creative, valuable, and unique literary works and this ability can be seen as one of the most fertile commonalities between literature and nature. Here, nature has been a source of survival needs and higher psycho-social needs and the process of writing a record of our very blissful and dreadful moments in conveying such needs.

The integral role that selected nineteenth century literary thoughts and perceptions have played and are still playing in the history of the ecological science, environmental ethics and human values pertinent to nature; readers and scholars can better appreciate the fundamental eco-critical insights of these writers. Here, literature has supposedly preserved certain human values at the heart of recorded relationships between man and land. Nature is the tangible vast that visualizes the conceptual and abstract cultural values of literature as an experiential ecological bit of truth. Literature shapes our perception of nature and cultivates a kind of universal culture that no one should be the only model of uniqueness but rather to be one of the valuable unique beings amidst other valuable different unique possibilities.
Culture and civilization are not axiomatically bound, but two fairly distinct concepts that can go side by side or even possibly oppose each other, as well. While culture and nature maintain valuable distinctions and uniqueness of individuals; civilization would try to copy the same supposedly preferable model in similar readymade frames. Here, eco-criticism, as an interdisciplinary approach, tries to bridge the gap between them and reconcile culture, civilization and nature, rather than idealizing nature or demonizing the urbanized city. Nature can be or is a fundamental force that shapes us as much as we shape it. While it would tackle materialistic interpretation of declining health, corrupted landscape, or pollution as a scientific regional concern, it would also make a universal call through the universal ecosystem, claiming that different elements and components of the system are interrelated, integrated and reciprocally influencing each other as shown in the poems of these two poets.

One can claim that eco-criticism has two concerns; the first is the physical environment and the relationship between literature and culture in environmental and biological senses. The second is eco-criticism in a deeper level in arts and literature that seeks the relationship between land and writing and offers common grounds for the reconciliation between man, nature and himself in a humane and psychological sense.

\section{Works Cited}

Ayinuola Fortress Isaiah. The Natural Environment in the Selected Poems of John Keats and Niyo Osundare: An Eco-critical Perspective. A Ph.D A Thesis Submitted to the Department of Languages, College of Development Studies (CDS) of Covenant University Ota, Nigeria2013

Britto John. "An Eco-critical Reading of William Wordsworth's "Tintern Abby" Academic Research International. 2. 1 (2012) 720 
Carter Ronald and McRae John The Routledge History of Literature in English. Britain \& Ireland With a Foreword by Malcolm Bradbury London: Routledge, 1997

Eruvbetine, A.E; -Beauty: -The Keatsian Aesthetic Ideal. University of Lagos. Anglica Posnaniensia XVII, 1985. 251-69. Print.

Hazlitt William, Lectures On English Poets\&The Spirit Of The Age, Great Britain:Aldine

Press.Letchworth.Herts:1967),252-253

Heffernan James A. W. Wordsworth on Imagination: The Emblemizing Power. PMLA, 81.5 (1966), pp. 389399

Hitt Christopher. "Toward an Ecological Sublime" New Literary History, 30, 3 (1999) 603-623

Hochman, Jhan. "Green Culture Studies: an Introductory Critique of an Emerging Discipline." Academic Journal Article From Mosaic (Winnipeg) 30. 1 (1997): Web. 20 July 2013

Hutchings, Kevin. "Ecocriticism in British Romantic Studies." Literature Compass 4. 1 (2007): 172-202 Project Muse. Web. 08 August 2013

"John Keats." Poetry Foundation. Poetry Foundation, n.d. Web. 02 March 2017.

https://www.poetryfoundation.org/poems-and-

poets/poets/detail/john-keats

Kant Emmanuel. Critique of Pure Reason. Translated and Edited by Paul Guyer. Cambridge University Press I998

I $\mathrm{L}=$ The Letters of John Keats, 1814-1821, ed. Hyder Edward Rollins, 2 VOIS. (Cam- bridge, MA: Harvard University Press, 1958).

Love, Glen. Practical Ecocriticism: Literature, Biology, and the Environment. Charlottesville; London: University of Virginia Press, 2003. Print
Marsden, William. "Society Ecology and Nineteenth Century Urban Education." History of Education Quarterly 23. 1 (1983): 29-53 Project Muse. Web. 28 May 2013

Potkay Adam Wordsworth and the Ethics of Things. PMLA, 123. 2 (2008),390-404

Reddy Sanjay M. The Eco-criticism: a New Perspective of Literary Studie. Smt. Kesharbai Lahoti Mahavidyalaya, Amravati, 1.2. 2015

Rueckert, William. "Literature and Ecology: an Experiment in Ecocriticism." The Ecocriticism Reader: Landmarks in Literary Ecology Ed. Cheryll Glotfelty and Harold Fromm. University of Georgia Press. 1996. 105-124, Print

Sanders Andrew. The Short Oxford History of English Literature. Oxford University Press. 1994.

Sarker Sunil Kumar, A Companion to Wordsworth,(Atlantic Publishers:2001),334-335

Thorne Sarah. Mastering Poetry. Palgrave Macmilan. 2006

White Irving "John Keats as a Critic" The Sewanee Review 34,

No. 4 (1926) $451-465$

"William Wordsworth." Poetry Foundation. Poetry Foundation, n.d. Web. 02 March 2017.

https://www.poetryfoundation.org/poems-andpoets/poets/detail/william-wordsworth 